\title{
Absorptive Capacity and Its Role for the Company Growth and Competitive Advantage: The Case of Frauenthal Automotive Toruń Company
}

\author{
Andrzej Lis ${ }^{1}$, Agata Sudolska ${ }^{2}$
}

\begin{abstract}
The aim of the paper is to study the role of absorptive capacity for the company growth and competitive advantage through open innovations. The case of Frauenthal Automotive Torun is used to explore how the routines and best practices associated with the firm absorptive capacity contribute to its success. The case study is to validate the thesis that through developing skills to recognize valuable knowledge in the environment, acquire this knowledge, assimilate, transform and develop it companies are able to apply and benefit from open innovations in order to grow and strengthen their competitive advantages. In order to achieve the aim of the paper the following research objectives have been set: (1) to identify the lessons and best practices applied in Frauenthal Automotive Torun in relation to the company absorptive capacity; (2) to analyze the relationships between the concepts of absorptive capacity and open innovation; (3) to exemplify and discuss the outcomes of the company absorptive capacity in regard to innovations, company growth and competitive advantage.
\end{abstract}

Keywords: absorptive capacity, open innovation, company growth, competitive advantage

\section{INTRODUCTION}

Absorptive capacity is one of the concepts explaining how companies build up their abilities to learn from external partners and use the new knowledge to innovate and grow. Absorptive capacity is defined as "a set of organizational routines and processes by which firms acquire, assimilate, transform and exploit knowledge to produce a dynamic organizational capability" (Zahra \& Goerge, 2002, p. 186). It encompasses the company ability to identify external

1 Andrzej Lis, Dr., Nicolaus Copernicus University, Faculty of Economic Sciences and Management, ul. Gagarina 11, 87100 Toruń, Poland. Doctrine and Training Centre of the Polish Armed Forces, Bydgoszcz, Poland; andrzejlis@econ.umk.pl. 2 Agata Sudolska, Dr. hab., Professor UMK, Nicolaus Copernicus University, Faculty of Economic Sciences and Management, ul. Gagarina 11,87-100, Toruń, Poland; aga@econ.uni.torun.pl. 
knowledge and recognise its value, combine new elements of knowledge within the company knowledge base and apply new knowledge to create innovations in order to contribute to business success (Cohen \& Levinthal, 1990; Zahra \& George, 2002). The idea of absorptive capacity popularized by Cohen and Levinthal (1990) has been re-examined and reconceptualised by Zahra and George (2002) and Todorova and Durisin (2007). Zahra and George (2002) distinguish between two types of absorptive capacity: potential absorptive capacity (including knowledge acquisition and assimilation) and realized absorptive capacity (encompassing knowledge transformation and exploitation). Todorova and Durisin (2007) criticize the reconceptualization proposed by Zahra and George (2002), reject differentiation between potential and realized absorptive capacity and postulate reintroducing the elements of the original concept by Cohen and Levinthal (1990) such as "recognizing the value" of external knowledge.

The concept of absorptive capacity has been the subject of numerous research publications in recent 25 years. Nevertheless, there are still some aspects worth being explored. The relationships between the concepts of absorptive capacity and open innovations as well as the role of absorptive capacity for the company growth and competitive advantage seem to be such areas of great potential for further research. Having analyzed various approaches to measuring absorptive capacity, $\operatorname{Duchek}(2013$, p. 325) concludes that previous methods mainly based on the quantitative perspective "do not address the complexity of the construct and barely recognize its routine-based character". As a remedy she suggests to employ "a practice-based approach and the use of qualitative methods, such as ethnographies and narratives, [which] are the most appropriate methods for identifying the routines and practices that build absorptive capacity". Therefore, the qualitative approach focused on the case study analysis is applied in the paper in order to explore the issue of absorptive capacity.

The aim of the paper is to contribute to the knowledge and research on the role of absorptive capacity for the company growth and competitive advantage. The empirical contribution of the paper concerns the case of Frauenthal Automotive Torun that is used to explore how the routines and best practices associated with the firm absorptive capacity contribute to its growth and success. The main research question to be answered in the case study analysis is the following: Is a company able to realize the potential of open innovations in order to grow and strengthen its competitive advantage through developing skills to recognize valuable knowledge in the environment, acquire this knowledge, assimilate, transform and develop it?

Taking into account the aforementioned research problem, the following detailed questions have been addressed: (1) what are the lessons and best 
practices identified in Frauenthal Automotive Torun within the absorptive capacity process?; (2) what are the relationships between the concepts of absorptive capacity and open innovation?; (3) what are the outcomes of the Frauenthal Automotive Torun absorptive capacity in regard to innovations, company growth and competitive advantage?

The paper consists of two parts: the theoretical grounding and the empirical research based on the case study analysis. The theoretical part, first of all, outlines the assumptions of the concept of absorptive capacity. Secondly, the relationships between the concepts of absorptive capacity and open innovation are discussed. Thirdly, the role of absorptive capacity for the firm growth and competitive advantage is analyzed. The literature review provides the foundation for the empirical research. The empirical part of the paper starts with the presentation of the context and the method of study. Then, absorptive capacity lessons and best practices identified in Frauenthal Automotive Torun are studied. Finally, the mechanisms and outcomes of external knowledge application in the company under the study are discussed in order to analyze the role of absorptive capacity for the company innovations, growth and competitive advantage.

\section{THEORETICAL GROUNDING}

\section{The concept of absorptive capacity}

The emergence of the concept of absorptive capacity is associated with the studies by Cohen and Levinthal (1989; 1990). Absorptive capacity is defined as "the ability of a firm to recognize the value of new, external information, assimilate it, and apply it to commercial ends" (Cohen and Levinthal, 1990, p. 128). Zahra and George (2002, p. 186) reconceptualize absorptive capacity and characterize it as "a set of organizational routines and processes by which firms acquire, assimilate, transform and exploit knowledge to produce a dynamic capability". Absorptive capacity is based on individual abilities of organization members (Cohen and Levinthal, 1990, p. 131). However, as observed by Zahra and George (2002, p. 186) and Duchek (2013, p. 313), the concept of absorptive capacity is perceived mainly as an organizational construct.

Zahra and George (2002, p. 185) point out that the role of absorptive capacity is stressed in strategic management (cf. Lane \& Lubatkin, 1998, Nahapiet \& Ghosal, 1998), technology management (cf. Schilling, 1998), international business (cf. Kedia \& Bhagat, 1988) and organizational economics (cf. Glass \& Sagi, 1998). Duchek (2013, p. 313) places the construct of absorptive capacity "between the fields of organizational learning (Huber, 
1991; Kim, 1998) knowledge management (Chiva \& Alegre, 2005; Oshri, Pan \& Newell, 2006), and dynamic capabilities (Mowery, Oxley, \& Silverman, 1996)". Taking into account the aim of our study, the special attention is focused on relationships of absorptive capacity with strategic management, organizational learning and dynamic capabilities. From the strategic management point of view, the concept of absorptive capacity is usually associated with the assumptions of the resource-based view. Following this way of thinking, Nahapiet \& Ghosal (1998) find social and intellectual capitals to be key sources of the company competitive advantage. Simultaneously, they claim that "social capital facilitates the development of intellectual capital by affecting the conditions necessary for [knowledge] combination and exchange to occur" (Nahapiet \& Ghosal, 1998, p. 250). Lane \& Lubatkin (1998, p. 462) "shift the unit of analysis of [Cohen's and Levintal's] construct from the firm to the 'student-teacher' pairing (the learning dyad)". They focus their study on relative absorptive capacity based on the assumption that the ability of a student-firm to effectively absorb new knowledge from its partner depends on relative characteristics of both organizations. The relationship between absorptive capacity and organizational learning is thoroughly studied by Anderson and Sun (2010, p. 130) who suggest that "absorptive capacity (a dynamic capability) is a concrete example of organizational learning that concerns an organization's relationship with new external knowledge". As regards dynamic capabilities, Mowery et al. (1996) include the issue of absorptive capacity in their study of inter-firm knowledge transfer within strategic alliances. They use absorptive capacity to "explain the effectiveness of technology-based capability transfer" (Mowery et al., 1996, p. 78) and suggest that absorptive capacity plays an important role for acquiring capabilities from alliance partners.

Zahra and George (2002, pp. 189-191) identify four components of absorptive capacity and group them into two categories: potential absorptive capacity (knowledge acquisition and assimilation) and realized absorptive capacity (knowledge transformation and exploitation). In their model, knowledge acquisition "refers to a firm's capability to identify and acquire externally generated knowledge that is critical to its operation". Knowledge assimilation is defined as "the firm's routines and processes that allow it to analyze, process, interpret and understand the information obtained from external sources". Knowledge transformation is explained as "a firm's capability to develop and refine the routines that facilitate combining existing knowledge and the newly acquired and assimilated knowledge". Knowledge exploitation encompasses "the routines that allow firms to refine, extend and leverage existing competencies or to create new ones by incorporating acquired and transformed knowledge into operations". 
The classification of the processes of knowledge acquisition, assimilation, transformation and exploitation is used by Jansen, Van Den Bosch and Volberda (2005) in their study of absorptive capacity intra-organizational antecedents. The Zahra and George model distinguishing between potential absorptive capacity and realized absorptive capacity is adopted, among others, by Fosfuri and Tribó (2008). Anderson and Sun (2010) study the relationships between absorptive capacity (based on the framework by Zahra and Gorge, 2002) and organizational learning (the 4 I model). The 41 model proposed by Crossan, Lane and White (1999) corresponds to four processes of organizational learning i.e. intuiting, interpreting, integrating and institutionalizing. Anderson and Sun (2010, pp. 141-146) assume the involvement of organizational learning processes into the dimensions of absorptive capacity in the following way:

- knowledge acquisition - intuition and interpretation (individual and group learning);

- knowledge assimilation - interpretation (group learning);

- knowledge transformation - integration (group and organizational learning);

- knowledge exploitation-institutionalization (organizational learning).

The aforementioned examples point out that the reconceptualization of the absorptive capacity concept by Zahra and George (2002) is widely discussed and accepted. Nevertheless, there are some researchers (e.g. Todorova \& Durisin, 2007) who criticize this reconceptualization and postulate reintroducing the elements of the original concept by Cohen and Levinthal (1990) such as "recognizing the value" of external knowledge. Todorova and Durisin (2007) perceive knowledge assimilation and knowledge transformation as two alternative processes instead of sequential relationship between them as proposed by Zahra and George (2002). Moreover, Todorova and Durisin (2007) are very skeptical as regards distinguishing between potential and realized absorptive capacity claiming that their definitions are ambiguous and unclear. Combining the approaches represented by Cohen and Levinthal (1990) and Zahra and George (2002), and taking into account the objections reported by Todorova and Durisin (2007), Sudolska and Lis $(2014$, p. 118) define the scope of absorptive capacity components in the following way: "identifying and recognizing external knowledge, processing and understanding it, combining it with existing knowledge and applying new knowledge to commercial ends".

From the practical point of view, the mechanisms and practices included into company absorptive capacity are the issues of paramount importance. For instance, in their model of absorptive capacity, Zahra and George (2002, p. 194) identify the so-called social integration mechanisms which enable 
companies to benefit from the potential of their absorptive capacities (shift from potential absorptive capacity to realized absorptive capacity). Such mechanisms may be of formal character (e.g. coordinators) or informal character (e.g. social networks). In her case study of a medium-sized, familyowned, high-tech German company operating in an engineering industry, Duchek (2013, pp. 324-325) focuses on knowledge absorption practices. Among the examples of such practices she identifies: technology scouting (for knowledge acquisition), face-to-face communication (for knowledge assimilation) and informal promotion of new ideas by key organization members (for knowledge exploitation). Technology scouting refers to "a structured observation and early recognition of opportunities, relevant changes and technological developments". Technology scouting is practiced through an active search for knowledge sources in the Internet, branch and scientific publications for external knowledge to be employed into company projects; participation in conferences, forums, training sessions in order to be acquainted with new knowledge in the field and importing identified knowledge into an organization. Face-to-face communication is found a prerequisite to effectively share knowledge, discuss complex issues, provide/receive feedback and establish networks within an organization. The roles of key leaders' engagement encompass: introducing new ideas into an organization, convincing the company stakeholders in order to get all required approvals and playing as change agents.

\section{The relationships between the concepts of absorptive capacity and open innovation}

As said before, absorptive capacity is commonly understood as firm's ability to recognize the value of new knowledge, to assimilate it and apply it to commercial ends (Cohen \& Levinthal, 1990, p. 128). Based on this approach, we would like to focus on the links between both: the concepts of open innovation and absorptive capacity. Combining these two concepts leads to the insight into the role of absorptive capacity in opening up innovation processes of a firm (Lewandowska, 2015). The issues of the relationships between absorptive capacity and open innovation have drawn attention of several researchers providing different proposals related to absorptive capacity in the context of open innovation paradigm (Lichtenthalter \& Lichtenthalter, 2009; Hughes \& Warenham, 2010; Wallin \& von Krogh, 2010; King \& Lakhani, 2011; Robertson, Casali \& Jacobson, 2012; Lewandowska, 2015).

The idea of open innovation has received an increased attention over the past decade (Chesbrough, 2006; Laursen \& Salter, 2006; Ebersberger, Herstad, 
Iversen, Som \& Kirner, 2011). The concept describes a cognitive framework for an organization's strategy to profit from innovativeness. Its fundamental idea concerns opening up firm's innovation process (Huizingh, 2011). Open innovation is an approach that focuses on the need for any organization to transcend its boundaries and concentrate on purposive inflows and outflows of information and knowledge to accelerate organizational internal innovativeness, but also to allow the external market users to benefit from organization's innovations. The use of above mentioned purposive inflows of knowledge is called inbound open innovation, while purposive outflows are described as outbound open innovation.

In practice, open innovation leads to the increase of organization's boundaries permeability and the need to interact with its environment in more open ways. Open innovation processes combine internal and external ideas into organization's architecture and system. According to the mentioned approach, various projects can be launched from internal or external sources but on the other hand the projects can go to the market in many ways, for example through outlicensing or a spin-off venture company, in addition to entering the market through the organization's sales channels (Chesbrough, 2008). The literature includes a number of studies that highlight the positive relationship between increased linkages and knowledge flows from several external sources that an organization uses and the improved innovation outcomes of this organization (Fey \& Birkinshaw, 2005; Keil, Maula, Schildt \& Zahra, 2008; Leiponen \& Helfat, 2010). Above mentioned studies suggest that the increased openness towards external partners results in the increased innovation outcomes for an organization.

While searching for the links between absorptive capacity and open innovation we have to point out that the use of purposive inflows of knowledge, called inbound open innovation that concerns internal usage of knowledge acquired from external sources, directly refers to company's absorptive capacity. This point of view is shared by most researchers in the field. Hughes and Warenham (2010), who have held the comprehensive review of relevant literature (Cohen \& Levinthal, 1990; Lane \& Lubatkin, 1998; Tsai, 2001; Lane, Salk \& Lyles, 2001; Zahra \& George, 2002; Liao, Welsch \& Stoica, 2003; Jansen et al., 2005; Lane, Koka \& Pathak, 2006) conclude with the statement that most-cited studies of absorptive capacity focus mainly on inbound activities. Simultaneously, Lichtenthaler and Lichtenthaler highlight that absorptive capacity as the concept paying attention to utilizing external ideas and knowledge inside a company, somehow neglects other significant processes related to knowledge management, e.g. internal knowledge creation that seems to be important for open innovation processes (Lichtenthalter \& Lichtenthalter, 2009). 
Considering the relationships between the concepts of absorptive capacity and open innovation, it should be underlined that implementing open innovation in an enterprise has a strong impact on its resources and capabilities and thus on its competitiveness. Due to this opening up, enterprise's innovation processes entails a need of developing its internal dynamic capabilities, including absorptive capacity (Zahra \& George, 2002; Lewandowska 2015).

On the other hand, tracking works of Cohen and Levinthal (1990) and King and Lakhani (2011) leads us to the assumption that opening up firm's innovation processes influence the increase of its absorptive capacity. Combining Cohen and Levinthal's (1990) and King and Lakhani (2011) approaches allows us to state that absorptive capacity comprises two elements:

- firm's capacity to adopt ideas and knowledge from external sources which may be called "adoption capacity",

- firm's capacity to utilize ideas and knowledge from external sources and create new inventions which may be called "invention capacity".

King and Lakhani empirically prove that experience with adoption of externally created inventions increases both adoption capacity and invention capacity (King \& Lakhani, 2011). Experience concerning adoption allows the company to better and easier absorb new external knowledge. This suggests that organization's experience in the field of open innovation leads to the enhancement of absorptive capacity, although according to the traditional point of view it is absorptive capacity which contributes to the implementation of open innovations. The relationships between the concepts of absorptive capacity and open innovation are presented in Figure 1.

In Figure 1, we make an attempt to accommodate and present graphically the variety of approaches to define absorptive capacity and enumerate its components. Then, we embed the construct of absorptive capacity in the context of open innovation. The model is a compromise between the re-conceptualizations of absorptive capacity by Zahra and George (2002) and Todorowa and Durisin (2007). It is constructed around "organizational routines and processes by which firms acquire, assimilate, transform and exploit knowledge" (Zahra \& George, 2002, p. 186). It distinguishes between potential and realized absorptive capacity (Zahra \& George, 2002) as well as adoption and invention absorptive capacity (King \& Lakhani, 2011). However, following the recommendations by Todorowa and Durisin (2007), we added the component of knowledge recognition. Moreover, we consider knowledge assimilation and transformation as alternative processes not necessarily following each other as a sequence. In our model inbound open innovation that concerns internal usage of knowledge acquired from external 
sources directly refers to company's absorptive capacity. Simultaneously, the outcomes of company absorptive capacity embodied in innovations may outflow to the market through outlicensing or sharing knowledge with partners (outbound open innovations).

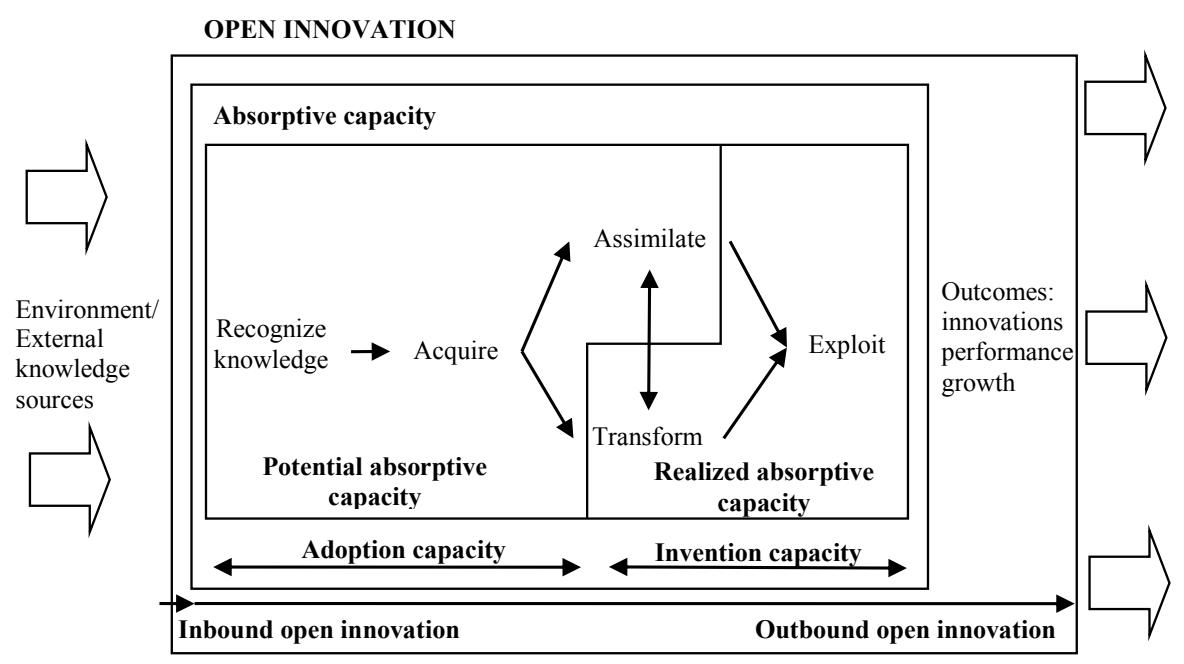

Figure. 1. Absorptive capacity in an open innovation context

Source: Elaborated by authors, inspired by Hughes and Wareham (2010, p. 333).

While considering the issues concerning the relationships between absorptive capacity and open innovation, Wallin and von Krogh (2010) suggest that five stages of the open innovation process can be distinguished:

- defining innovation process,

- identifying innovation-relevant knowledge,

- selecting an appropriate integration mechanism,

- creating effective governance mechanisms,

- balancing incentives as well as controls.

Despite these authors analyze all five stages, they pay special attention to the one that is knowledge integration which in fact is a component of the invention capacity which, as previously stated, refers to organization's capacity to utilize (and integrate) external knowledge and thus create novelty.

Wallin and von Krogh (2010) point out that innovation-oriented executives have to predict particular activities needed to be taken as moving through the whole innovation process, e.g. from the idea to a product launch in the market. Going further, performing these activities requires specific innovation-relevant knowledge that exists inside or outside a firm. While such knowledge is found outside a firm, choosing an appropriate integration mechanism becomes necessary. As highlighted by aforementioned authors, 
the issue of enabling knowledge integration refers to specifying the ways how employees, teams, as well as some sources external to the firm, contribute to subsequent stages of innovation process (Wallin \& von Krogh, 2010, p. 149).

While considering the issue of knowledge integration (as a part of the open innovation process), it seems central here to focus on firm's receptivity which can be described as a kind of enterprise's attitude towards new knowledge. The more receptive both executives and employees are to new ideas and knowledge, the more likely they are to learn and change. Firm's openness towards novelty combined with its receptivity is directly related to its absorptive capacity. An enterprise receptivity highly depends on the availability of time and resources (money, people, data bases, knowledge etc.) assigned to engage in the processes of gathering knowledge and embedding it within its own routines through employees training or investment in new equipment (Child, Faulkner \& Tallman, 2005, pp. 285-286). Therefore, it influences firm's invention capacity being a component of absorptive capacity. This explains why some companies embedded in several business relationships and networks that allow to absorb knowledge, remain noninnovative. It can be assumed that they do not possess enough invention capacity and in turn they are not able to assimilate the absorbed knowledge and capture value from it.

\section{The role of absorptive capacity for firm growth and competitive advantage}

Among pertinent issues regarding a firm's absorptive capacity, there is a necessity for underling its importance for company growth. Having to bear in mind that there are different views regarding firm growth value (Chandler \& Jansen, 1992; Gartner, 1997; Lee, Smith, Grimm \& Schomburg, 2000; Markman \& Gartner, 2002), we refer to the perspective according to which company growth is perceived as a precursor to achieve its sustainable competitive advantage (Lee et al., 2000; Markman \& Gartner, 2002). In recent decades it has been also recognized that strengthening company's absorptive capacity brings about several outcomes related to its growth and competitive advantage. As highlighted by Teece, "the competitive advantage of firms in today's economy stems not from market position, but from difficult to replicate knowledge assets and the manner in which they are deployed" (Teece, 1998, p. 62). This opinion may be explained by the fact that knowledge assets meet the most important requirements of the strategic resources considered to be the prerequisites for a firm's long term competitive advantage i.e. they are: valuable, rare, difficult to imitate and difficult to be replaced by other resources (Barney, 1991). 
Among the obvious advantages of having access to new external knowledge both the researchers and practitioners mention: lower costs, shorter time to market, number of innovations increase, more sales and other financial benefits as well as non-financial benefits e.g. clarifying company's core competences (Huizingh, 2011; Rigby \& Zook, 2002). As recognizing and then acquiring new knowledge a company activates its absorptive capacity, it can be said that having an access to new external knowledge is a prerequisite for generating any absorptive capacity outcomes. It must be remembered that analyzing this kind of outputs requires taking into account both commercial outcomes (e.g. new products, patents) and knowledge outputs (e.g. technical, scientific or organizational knowledge). Despite the category of the realized outcomes, all of them have an impact on a company's future absorptive capacity (Lane et al., 2006). In other words, firm's focus on enhancing its absorptive capacity and generating particular results (new values) naturally influences the possibility of firm growth.

While considering the issue of the absorptive capacity importance for firm growth, it seems worth to examine the motives of the firms searching for external knowledge acquisition and exploitation. As highlighted by several authors, the empirical research proves that offensive motives are much more frequent than defensive ones (Chesbrough \& Crowther, 2006; Van de Vrande, de Jong, Vanhaverbeke \& de Rochemont, 2009). Due to the fact that focusing on absorbing knowledge from outside the company in order to transform it into new value is definitely offensive activity, we assume that enterprises which concentrate on enhancing their ability to recognize new needed knowledge, then assimilate and transfer it to apply it to commercial ends, also aim at their growth (and development).

While discussing about enterprise resource base and its links to absorptive capacity and growth, it seems necessary to point out that Zahra and George (2002, p. 185) perceive absorptive capacity as "a dynamic capability pertaining to knowledge creation and utilization that enhances a firm's ability to gain and sustain a competitive advantage". As it is commonly known, dynamic capabilities are enterprise routines allowing the executives to change company's resource base through acquiring, shedding, integrating as well as recombining resources in order to create new value and strengthen firm's competitive advantage (Eisenhardt \& Martin, 2000; Sapienza, Autio, George \& Zahra, 2006). What is worth underlying, Zahra and George (2002) distinguish between the role of potential absorptive capacity (including knowledge acquisition and assimilation) and realized absorptive capacity (knowledge transformation and exploitation) for competitive advantage. They assume that potential absorptive capacity supports sustaining competitive advantage through flexibility in resource reconfiguration, effective timing 
of capability deployment and lower costs. However, realized absorptive capacity is required in order to build up company competitive advantage with innovations and product development. Innovative processes or products result from company realized absorptive capacity which involves knowledge transformation and exploitation. These new products or processes allow to introduce the modifications within competitive tools used by the firm on the market. This in turn leads to gaining competitive advantage over company's rivals.

Simultaneously, Zahra and George highlight that a strong regime of appropriability is necessary to protect company knowledge assets and realize effectively its absorptive capacity through innovations due to high costs of potential imitation by competitors (Zahra \& George, 2002, p. 195-197). The regime of appropriability is needed because accumulating knowledge both from possible internal and external sources is of strategic importance today. As mentioned before, knowledge has been recognized as one of firm's strategic assets. Due to this, on one hand the executives have to focus on acquiring new knowledge and reconfiguring a possessed resource base, but on the other hand they must draw their attention to retaining the uniqueness and value of their knowledge assets that allow a firm to generate innovations and achieve better results than competitors do (Jashapara, 2004).

Taking into account the aforementioned considerations, we can say that enhancing firm's absorptive capacity seems to have a strong impact on the firm's growth and competitive advantage.

\section{Absorptive CApacity in Frauenthal Automotive TORuń}

\section{The context of the study}

Frauenthal Automotive Toruń (formerly Pol-Necks) is a medium size company (ca. 150 employees) operating in the automotive component industry. The company supplies world leading truck manufacturers with u-bolts. U-bolts are metal elements of $U$ letter shape with screw threads on both sides. They may be manufactured both in hot and cold bending technology. U-bolts produced by Frauenthal Automotive Torun are used for mounting springs on the axles of heavy vehicles to fasten a truck chassis and a body. Due to their critical impact on vehicles safety, u-bolts are to meet very high quality standards. Key customers of the company include: Volvo (32\% of sales in 2013), Scania (27\%), BPW (21\%) and Renault Trucks (15\%). Frauenthal Automotive Toruń is the industry leader in developing and producing u-bolts for commercial vehicles in Europe and the second top world producer of u-bolts. Moreover, Frauenthal Automotive Torun manufactures pins and screws. The company 
products are used for the following applications: heavy duty trucks, commercial vehicles, heavy duty trailers, steel constructions (e.g. windmills, cranes), agriculture machines and tractors, construction machines, buses and coaches and mechanical engineering.

Pol-Necks was established in Toruń, Poland in 1993 by a Swedish entrepreneur. From its beginning, the company has been operating in the metal processing branch. In the history of the company, there are three milestones worth mentioning. Firstly, in 2000, the manufacturing of u-bolts started and since this date the company has grown to become the leader of the European u-bolt market. Secondly, in 2007, the company was acquired by an Austrian corporation Frauenthal Automotive Components. As a consequence of the takeover, the company reorganization was implemented which resulted in the shift from the family business model to the corporate business model. The company changed its name to Frauenthal Automotive Torun in 2012 which symbolically crowned the reorganization process. The third turning point was the world economic crisis which had a significant, negative influence on the company operations. In 2009, the yearly production of u-bolts plummeted to 750000 pieces from the level of 2000000 one year earlier. Due to its resilience, the company survived hard times and it restored the former level of production in 2010. Nowadays, the company output is 2500000 pieces of u-bolts per year. In, 2011 Frauenthal Automotive Toruń implemented management systems: Quality Management System ISO/TS 16949:2002, Environmental Management System ISO 14001:2004 and Safety Management System OHSAS 18001:2007. Since 2010, the company has been introducing and developing the Lean Management program.

The company proudly declares its "focus to develop new innovative products" as well as "continuous productivity investments and dedication to Lean Manufacturing". Due to its dedication to continuous learning, positive organizational potential (cf. Lis, 2013) as well as organizational culture and climate conducive to knowledge management, Frauenthal Automotive Toruń seems to be an interesting case to study absorptive capacity practices and its role for the company innovations, growth and competitive advantage.

\section{The method of the study}

The single case study analysis of the Frauenthal Automotive Torun company is the research method applied to achieve the aim of the paper. The main advantage of the case study method is using empirical evidence from real organizations to contribute to the knowledge in the field (Myers, 2010). Moreover, as observed by Duchek (2013), the case study method has a great potential to study the issue of absorptive capacity. The process of designing 
and conducting the research has encompassed the following stages (Yin, 2010; Strumińska-Kutra \& Koładkiewicz, 2012; cf. Patton \& Appelbaum, 2003; Stake, 2010): (1) defining study questions and propositions; (2) selecting the unit of analysis and the sample within the studied case; (3) planning and collecting data; (4) analyzing data; and (5) writing a report.

In order to achieve the aim and objectives of the paper, the following study questions were set: (1) how does Frauenthal Automotive Toruń recognize the value of external knowledge, acquire it, assimilate, transform and exploit? (2) what are the relationships between absorptive capacity and open innovations in the company under the study? (3) how does the company absorptive capacity contribute to its innovations, growth and competitive advantage? The aforementioned study questions provided the foundation for the following proposition to be validated in the research process: through developing skills to recognize valuable knowledge in the environment, acquire this knowledge, assimilate, transform and develop it companies are able to realize the potential of open innovations in order to improve their performance and grow.

The single case study of Frauenthal Automotive is chosen as the unit of analysis. The single case study enables us to study thoroughly and to understand the unit of analysis within its context. Certainly, we are aware that any attempts to generalize on the basis of the single case study are challenging while pattern matching with theoretical assumptions and explanation building become very difficult (Strumińska-Kutra \& Koładkiewicz, 2012, p. 5).

The following methods were applied to collect the data necessary for analysis: interviews, questionnaires and observation. The research process consisted of three stages. First of all, the pilot interview with a representative of company management was conducted in July 2015 in order to ensure that Frauenthal Automotive Torun was a relevant case to study the relationships between absorptive capacity, open innovations and firm growth and competitive advantage. Moreover, the pilot study enabled us to acquire general understanding of issues related to absorptive capacity in the company. Secondly, in October 2015, the questionnaire survey was conducted. Its aim was to assess the level of absorptive capacity components in Frauenthal Automotive Toruń. Thirdly, in order to collect data necessary for thorough qualitative analysis, interviews with the representatives of the management team were conducted in October 2015.

The questionnaire survey was conducted among the members of the board and employees of the following departments: sales, finances, HR, logistics and production. Questionnaires were distributed among employees having knowledge of inter-organizational learning processes occurring between 
Frauenthal Automotive Torun and its external partners. Questionnaires were circulated via the HR Manager who was nominated the company main point of contact for this research project. In total, 15 employees contributed with their questionnaires. The questionnaire included the scales and items of potential and realized absorptive capacity proposed and validated by Jansen et al. (2005). Questions related to knowledge acquisition (6 items), knowledge assimilation ( 3 items), knowledge transformation (6 items) and knowledge exploitation ( 6 items). All of them referred to ongoing activities of the company.

There were five managers who contributed with interviews including: the chief executing officer, the member of the board responsible for sales and marketing, the sales manager, the chief of production and the HR manager. The interviewees were selected according to their position in the organizational structure and knowledge of inter-firm learning processes. Structured interviews were focused on three issues: absorptive capacity practices, its antecedents and impact on the firm growth and competitive advantage. The average length of each interview was between 60 and 90 minutes. Four of them were conducted at the company site in Toruń, Poland. One interview was taken outside the company location, in the city of Torun. The interviews were not recorded. The paper and pencil technique was applied to take notes. As regards time perspective, the attention was focused on ongoing operations and activities. When some references were made to the history of the company it encompassed the period of time since 2007, when the company was acquired by the Austrian corporation Frauenthal Automotive Components and shifted from the family business model to the corporate business model.

The findings from interviews and the questionnaire survey were confronted with the conclusions drawn by authors from their participatory observation of Frauenthal Automotive Torun learning processes while cooperating with the company. The selection of data collection methods ensured an appropriate level of triangulation. Following the principles of gathering evidence such as: triangulation, case study data base and chain of evidence (cf. Rowley, 2002) contributed to the quality level of the study.

\section{The level of absorptive capacity in Frauenthal Automotive Torun}

In order to to assess the level of absorptive capacity components in Frauenthal Automotive Torun and to confirm our prediction that the company is a good case to study the issues related to absorptive capacity we used the Jansen's et al. $(2005$, p. 1014) scales and items of potential and realized absorptive capacity to conduct the exploratory research. The questionnaire survey 
enabled us to make a comparative analysis of Frauenthal Automotive Torun absorptive capacity with the benchmark proposed by Jansen et al. (2005). The finding are presented in Table 1.

Table 1. The comparative analysis of Frauenthal Automotive Toruń absorptive capacity

\begin{tabular}{lllll}
\hline \multirow{2}{*}{ Variable } & \multicolumn{4}{l}{ Frauenthal Automotive Toruń $(\mathbf{n}=\mathbf{1 5})$ Benchmark $(\mathbf{n}=\mathbf{4 6 2})$} \\
\cline { 2 - 5 } & Mean & s.d. & Mean & s.d. \\
\hline Acquisition & 3.79 & 1.66 & 3.58 & 1.24 \\
Assimilation & 4.64 & 1.28 & 4.74 & 1.13 \\
Transformation & 4.34 & 1.42 & 4.61 & 0.83 \\
Exploitation & 5.07 & 1.66 & 5.26 & 1.72 \\
\hline
\end{tabular}

Source: Authors' research combined with data from Jansen et al. (2005, p. 1007).

The findings show that the absorptive capacity of Frauenthal Automotive Torun is very close to the benchmark used by Jansen et al. (2005). What is worth emphasizing, Frauenthal Automotive Torun capability to acquire new, external knowledge even exceeds the level of the benchmark. As regards knowledge acquisition, collecting industry information through informal means (e.g. lunches with industry friends, talks with trade partners) is the item which received the highest score. All the components of knowledge assimilation (i.e. quickly recognizing market shifts, understanding new chances to satisfy customers, as well as analyzing and interpreting changes in market demands) were assessed at the similar level close the mean value. In the field of knowledge transformation, the firm was found to be particularly good at intra-organizational knowledge transfer among the employees. In regard to knowledge exploitation, Frauenthal Automotive Torun seems to be a master in cooperating with its customers and responding to any complaints and weeks signals from them. The findings presented and discussed above confirm that Frauenthal Auomotive Torun is a good unit of the case study analysis aimed at exploring how the routines and best practices associated with the firm absorptive capacity contribute to its growth and success.

\section{Lessons and best practices in absorptive capacity}

Frauenthal Automotive Toruń makes attempts to identify, recognize and acquire new, external knowledge from numerous sources within its environment. Learning from other companies in the Frauenthal group and sharing with them lessons identified and best practices is the first and the most obvious field of the inter-firm knowledge transfer. The employees attend 
branch fairs and exhibitions in order to seek new solutions which could be applicable in the company. These are usually pre-planned knowledge-seeking activities. Before such events, clear learning objectives are set for participants who are expected to focus their attention on knowledge and solutions needed in the company. Nevertheless, lessons and ideas from other fields are also welcomed. The company closely cooperates with customers, responding to their needs and new requirements as well as to any complaints and weak signals. The respondents mention regular meetings with supply quality assurance managers of customers' companies. It is of particular importance in the automotive industry where customers review the processes and try to optimize them. Moreover, chosen employees are able to visit customer companies in order to learn about their processes (active learning) which is considered to be the reward for these employees. Similarly, it is necessary to highlight a close cooperation with suppliers of machines and equipment, who are engaged in solving company problems through organizing training sessions and sharing knowledge with Frauenthal Automotive Torun employees. Attending "supplier days" employees gain from the suppliers knowledge concerning the standards of their processes. What is very interesting is the direct learning relationship with competitors (competitive benchmarking). Competitors are visited by the members of the management team (CEO, directors). Managers bring to the company new ideas and share them with other employees. According to the rule of reciprocity competitors visit the company site. The examples of coopetition are the projects aimed at entering the Brasilian market and comparing the way and use of tools that were bought from the same supplier. Last but not least, the company cooperation with the academia should be mentioned. Frauenthal Automotive Torun cooperates with Nicolaus Copernicus University, Toruń and Casimir the Great University, Bydgoszcz. The company participates in scientific research projects in metal processing and management studies and applies their outcomes in business practice. The company receives students completing their apprenticeships and conducting study projects. As highlighted by interviewees, students and scholars bring to the company new, fresh ideas and they make employees more sensitive to valuable, external knowledge.

Frauenthal Automotive Torun has developed the set of the techniques and practices used for processing, understanding and assimilating new, external knowledge. The examples include: writing memos after meetings with external partners, visits etc., disseminating new knowledge among subordinates or colleagues during daily working meetings, discussing whether this new knowledge has potential to be exploited in the company. Employees meet and share new knowledge that they acquired during trainings, they prepare presentations and explain new ideas to others. What should be 
emphasized, employees expect from their managers and colleagues sharing knowledge they acquired while meeting external partners or visiting their sites. Sharing newly acquired knowledge is especially important for departments which, due to their position within the organizational structure, have less opportunities to cooperate with external partners. For instance, the production department acquires external knowledge through "gate keepers" (e.g. logistics provides them with "hot" knowledge from customers). In order to facilitate knowledge processing and knowledge sharing among employees the company established the electronic knowledge repositories (Frauenthalpedia, Management Planet).

Transforming new, external knowledge and combining it with prior existing knowledge is the next step within the absorptive capacity process. In Frauenthal Automotive Toruń, there are organized meetings where managers and employees analyze knowledge gaps and the ways to fill them with external knowledge. The respondents highlight positive outcomes of combining the external knowledge with the small suggestion system operating in the company in order to generate best solutions to identified problems and challenges.

Table 2. Frauenthal Automotive Toruń routines, lessons and best practices in absorptive capacity

\begin{tabular}{|c|c|c|c|}
\hline \multicolumn{2}{|l|}{ Potential absorptive capacity } & \multicolumn{2}{|c|}{ Realized absorptive capacity } \\
\hline Acquisition & Assimilation & Transformation & Exploitation \\
\hline $\begin{array}{l}\text { setting clear learning objectives } \\
\text { for employees attending branch } \\
\text { fairs and exhibitions in order to } \\
\text { seek new knowledge and solu- } \\
\text { tions } \\
\text { meeting regularly with the repre- } \\
\text { sentatives of customers (e.g. sup- } \\
\text { ply quality assurance managers) } \\
\text { visiting customers to learn about } \\
\text { their processes } \\
\text { visiting competitors (competitive } \\
\text { benchmarking) } \\
\text { engaging suppliers in solving com- } \\
\text { pany problems through organi- } \\
\text { zing training sessions and inviting } \\
\text { suppliers to share knowledge with } \\
\text { company employees } \\
\text { participating in research projects } \\
\text { conducted by academia } \\
\text { receiving students for apprenti- } \\
\text { ceships }\end{array}$ & $\begin{array}{l}\text { writing memos } \\
\text { after meetings } \\
\text { with external part- } \\
\text { ners, visits etc. } \\
\text { disseminating new } \\
\text { knowledge among } \\
\text { subordinates or } \\
\text { colleagues during } \\
\text { daily working me- } \\
\text { etings } \\
\text { discussing in te- } \\
\text { ams the potential } \\
\text { of new knowledge } \\
\text { to be exploited in } \\
\text { the company } \\
\text { establishing elec- } \\
\text { tronic knowledge } \\
\text { repositories }\end{array}$ & $\begin{array}{l}\text { organizing me- } \\
\text { etings where ma- } \\
\text { nagers and em- } \\
\text { ployees analy- } \\
\text { ze knowledge } \\
\text { gaps and the ways } \\
\text { to fill them with } \\
\text { external know- } \\
\text { ledge } \\
\text { combining exter- } \\
\text { nal knowledge } \\
\text { with the employ- } \\
\text { ee suggestion sys- } \\
\text { tem in order to } \\
\text { generate solutions } \\
\text { to identified pro- } \\
\text { blems and chal- } \\
\text { lenges }\end{array}$ & $\begin{array}{l}\text { promoting the cul- } \\
\text { ture of openness } \\
\text { to change (low } \\
\text { change resistan- } \\
\text { ce) and improve- } \\
\text { ment } \\
\text { promoting the } \\
\text { development of } \\
\text { "ambassadors of } \\
\text { changes" able to } \\
\text { persuade novelty } \\
\text { to other workers }\end{array}$ \\
\hline
\end{tabular}


The respondents emphasize a "good mixture" of factors related to organizational culture and employee attitudes and behaviors which are very conducive for exploiting new, external knowledge. First of all, the openness to change (low change resistance) regarding employees' attitudes is to be mentioned. Secondly, lots of employees working for the company for a long time have already adjusted to permanent changes and improvements. Thirdly, Frauenthal Automotive Toruń focuses on hiring so called "talents" who are engaged in their work. Fourthly, it always focuses on having some "ambassadors of changes" who are able to persuade novelty to other workers.

Summing up, the examples of routines, lessons and best practices related to absorptive capacity identified in Frauenthal Automotive Torun are collected in Table 2.

\section{Through open innovation to company growth and competitive advantage}

The absorptive capacity enables Frauenthal Automotive Torun to implement innovations leading to improvements and higher efficiency in production and administration processes, and in consequence to lower costs and higher quality.

The interviews with company managers provide some interesting examples of transforming and exploiting external knowledge for company innovations. U-bolts production is a niche business. Therefore, companies operating in the industry design and build new machines on their own. Designing new machines, due to some ideas imported from external partners, which led to the increase in the company productivity is enumerated among some of positive outcomes of realized absorptive capacity. In consequence, the number of workers necessary to operate the production line significantly decreased. However, Frauenthal Automotive Torun recognizes the role of positive organizational climate as well as employee attitudes and behaviors for innovation and company growth. Therefore, the company maintained the level of employment deploying workers from the production line to other functional areas. Another example of absorbing and exploiting external knowledge for company purposes supported aforementioned efforts to maintain the level of employment. Frauenthal Automotive Torun was able to successfully transfer particular operations (steel drawing) from one of its suppliers. This example of insourcing resulted in the company's higher control of material quality which has very positive market outcomes. One of the customers has already ordered products made of this kind of steel and two other companies are almost decided to order them. Moreover, Frauenthal Automotive Toruń became a "development partner" of such companies 
producing trucks as Man or Scania. In the metal processing industry, the quality of materials is one of the key success factors. Therefore, the company seeks opportunities to innovate within this area. The project aimed at obtaining the steel of higher quality in cooperation with one of German steel mills is one of the initiatives undertaken to achieve this objective. As a result the mill now is producing the new kind of steel that is specially dedicated for the company and has better technical parameters. Moreover, as a result of learning from the external environment, Frauenthal Automotive Torun has changed the way of marking its products. Previously, marks were vertically located on the product and the company changed it to horizontally marking. In turn this innovation resulted in lowering the risk of surface cracks and thus it improved the life-span of the product.

Acquiring new external knowledge allows the company to decrease the price of products. Due to frequent audits conducted by its customers, the company is obliged to introduce continuous improvement that should result in lowering costs and thus prices - these are the regulations concerning firms that are Original Equipment Manufacturing firms. Lowering costs allows more flexible price policy. As Frauenthal Automotive Torun is regarded as Original Equipment Manufacturing firm, it is obliged to deliver highest quality products, which builds company's reputation on the market. Leading truck producers do not cooperate with firms that are not Original Equipment Manufacturing companies. Due to this, permanent improvement and focus on innovations enable the company to win new contracts on the global market. Moreover, business contacts with truck production leaders are considered as recommendations for Frauenthal Automotive Toruń while entering new market areas.

There is another important outcome of Frauenthal Automotive Torun absorptive capacity and innovativeness: the change of employee mentality and behaviors. When employees realize that they can propose some changes which are introduced in the company and they are rewarded for this, they start thinking about new changes. It develops pro-innovating thinking and behaviors of workers. Employees are encouraged to propose improvement ideas and schemes which are assessed by special committee. If these changes result in some real improvements the employee is rewarded.

\section{Discussion}

The paper conceptual contribution is demonstrating the role and importance of enterprise absorptive capacity for its innovations, growth and competitive advantage. The considerations, both theoretical and empirical, presented in the paper have highlighted and proved that through developing skills to 
recognize valuable external knowledge, acquire it, assimilate, transform and develop this knowledge, firms are able to realize the potential of open innovations in order to improve their performance and grow.

The results presented in the paper are aligned with the evidence found in the relevant literature. The literature sources include a number of empirical investigations that highlight enterprise growth as one of significant benefits derived from developing firm's absorptive capacity. The outcomes related to organization's growth obtained through absorbing and utilization of new knowledge have been discussed by several authors (e.g. Zahra, Ireland \& Hitt, 2000; Autio, Sapienza \& Almeida, 2000; Sapienza et al., 2006, Naldi, 2010). Combining our research findings with those of aforementioned authors proves that focusing on acquiring new knowledge, assimilating it and then applying to commercial ends facilitates company's growth and success.

The empirical contribution of the paper refers to exploring how the routines and best practices associated with Frauenthal Automotive Torun absorptive capacity contribute to company growth and success. The paper contributes to the research on absorptive capacity issues through exploring the lessons and best practices applied in Frauenthal Automotive Torun within the absorptive capacity process; analyzing the links between the concepts of absorptive capacity and open innovation and discussing the outcomes of the Frauenthal Automotive Torun absorptive capacity development regarding innovations, company growth and competitive advantage.

Our findings provide useful managerial implications referring to the importance of both executives and employees consciousness regarding learning from external sources and change acceptance. We have sought to identify and point out the best practices applied in Frauenthal Automotive Torun within the absorptive capacity process. Our results provide us with the correctness that at each stage of absorptive capacity process (knowledge recognition, acquisition, assimilation, transformation and exploitation) the most significant variable is the mentality of managers and employees. Due to this, the executives should be aware that the first and necessary step to focus on absorptive capacity development, is introducing a system supporting both pro-innovative thinking and pro-innovative behaviors of all organization members.

Building such a system is directly related to all activities aimed at creating the organizational climate favorable to innovations (also called pro-innovative organizational climate). According to relevant literature, organizational climate refers to a reality containing the patterns of behavior, attitudes as well as feeling that describes organization's life (Isaksen, Lauer, Ekval \& Britz, 2001; Isaken \& Ekval, 2010). In other words, organizational climate is a kind of specific atmosphere within a firm that influences both executives and 
employees behaviors at work, particularly in terms of their motivation and commitment to work. Pro-innovative organizational climate supports the development, assimilation and utilization of new knowledge (Isaksen et al., 2001) and promotes the creation of any kind of novelty (products, services, ways of working, etc.).

As organizational climate favorable to innovations is a multi-dimensional issue, the relevant literature provides several typologies of variables and dimensions that are considered as critical to shape it within a company (Amabile, Conti, Coon, Lazenby \& Herron, 1996; Loewe \& Dominiquini, 2006; Hunter, Bedell \& Mumford, 2007; Isaken \& Ekval, 2010). Analyzing and combining those typologies, it should be underlined that introducing a system and climate supporting pro-innovative thinking and behaviors of employees is primarily associated with both managers and workers' intellectual stimulation, encouraging them to challenge and risk taking, providing time and resources for elaborating new ideas, promoting sharing knowledge, experience as well as new ideas, allowing disagreements between viewpoints which in fact means creative debating etc. Additionally, the trust and openness dimension is of significant importance. It seems critical to provide employees with emotional safety and feeling comfortable while sharing ideas with each other. Moreover, the way new ideas are treated is said to be critical to encourage pro-innovative thinking and behaviors of employees. The perception that innovative performance is tied to rewards in the organization is highly supporting while shaping pro-innovative system within a company. Also, promoting the message that the organization is committed to quality and originality of ideas is pointed out as one of creative climate dimensions (Hunter et al., 2007; Isaken \& Ekval, 2010).

Taking into account the aforementioned, it should be stated that in a company which aims at creating and commercializing innovations and so obtaining growth, considerable attention has to be placed on the policy of "small steps towards novelty". This means conducting the activities focused on first changing employees' mentality (way of thinking) and thus behaviors concerning changes and novelty. It is indisputable that only people who understand the need for change (innovation) and who derive benefits from it, are able to engage in any stage regarding absorptive capacity process. Moreover, it is critical that all organization members have a shared understanding of the importance of learning from outside the company which in fact means firm's receptivity. 


\section{CONCLUSION}

The case study of Frauenthal Automotive Torun encompasses a wide spectrum of activities related to both potential and realized (or adoption and invention) absorptive capacity of the firm. The analyzed enterprise has at its disposal necessary tangible and intangible resources to engage in the processes of gathering knowledge and embedding it within its own routines. The examples of enablers include: IT infrastructure supporting knowledge management (knowledge repositories such as Frauenthalpedia and Management Planet) and relational capital (encompassing among others customers, suppliers, higher education institutions). Implemented management systems and the Lean Management program as well as a high level of positive organizational potential establish the environment conducive to intra-organizational and inter-organizational learning. This in turn influences the invention capacity of the company and brings about several outcomes that would not have appeared without focusing on Frauenthal Automotive Torun absorptive capacity. Moreover, in an attempt to identify the routines and best practices regarding the company's absorptive capacity contributing to its growth and success in the field of innovativeness, we confirmed the relationship between the concept of absorptive capacity and open innovation. Through purposive inflows of knowledge the company not only develops its absorptive capacity and generates valuable outcomes, but also implements the idea of open innovation. It is indisputable that nowadays innovations are stimulated and created through purposive combining the knowledge from outside the company with its own knowledge resources. Thus, the company aimed at increasing its capacity to be innovative and competitive has to concentrate on opening up its boundaries both to purposive knowledge inflows and outflows. The desire to remain competitive motivates Frauenthal Automotive Torun to absorb new external knowledge but on the other hand to share some knowledge outcomes with several entities in company's environment. Our study provided insight into bilateral relationship between the enhancement of enterprise absorptive capacity and its experience concerning open innovation approach.

We have done our best to ensure the high quality of the study. Nevertheless, we are aware of its limitations. First of all, the single case study analysis is a method of exploratory nature which results are limited as regards any generalization. The specific characteristics of the company under the study, the industry it operates and the leader position the company occupies in the market may have an impact on any attempts to generalize our findings and "translate" them in a different context. Secondly, a limited sample of respondents and interviewees should be considered as a limitation. Having knowledge of inter-organizational learning processes occurring between 
Frauenthal Automotive Torun and its partners was the key factor for selection of the research sample within the unit of analysis. Therefore, taking into account the level of company employment (around 150 people) the number of informants was naturally limited. Thirdly, the research attention was focused on the company, while relative absorptive capacity based on the "learning dyads" (cf. Lane \& Lubatkin, 1998) including the studied company and its partners was nearly mentioned.

Finally, we are aware that our study is only one small step to explore thoroughly the issues of absorptive capacity and its relationships with open innovations, firm growth and competitive advantage. It would be interesting to broaden the analysis through interrelation between the activities undertaken by firms while implementing the open innovation approach and to emphasize on firm absorptive capacity development. Among implications of our study and the issues inspiring for further research we point out the issue of motivating employees to engage in the activities of all absorptive capacity process stages. We assume that remaining an innovative and competitive market actor implies the need to search for particular conditions that strongly influence employees attitudes towards innovations and their pro-innovative behaviors in the context of the firm's absorptive capacity. Such knowledge enables the executives intentionally create the conditions favourable for their success in the field of acquiring, transforming, and exploiting new external knowledge.

\section{Acknowledgements}

We would like to thank the anonymous reviewer for his/her effort, insightful comments and valuable recommendations for the improvement of the paper draft.

\section{Funding}

The project was funded by the Polish National Science Centre grant on the decision number DEC-2013/11/B/HS4/00691.

\section{References}

Amabile, T.M., Conti, R., Coon, H., Lazenby \& J., Herron, M. (1996). Assessing the work environment for creativity. Academy of Management Journal, 39(5), 1154-1184.

Autio, E., Sapienza H.J. \& Almeida, J.G. (2000). Effects of age at entry, knowledge intensity, and imitability on international growth. Academy of Management Journal, 43(5), 909-924. 
Barney, J. (1991). Firm resources and sustained competitive advantage. Journal of Management, 17(1), 99-120.

Chandler, G.N. \& Jansen, E. (1992). The founder's self-assessed competence and venture performance. Journal of Business Venturing, 7(3), 223-236.

Chesbrough, H. (2006). Open business models: how to thrive in the new innovation landscape. Boston: Harvard Business School Press.

Chesbrough, H. (2008). Open innovation: a new paradigm for understanding industrial innovation. In H. Chesbrough, W. Vanhaverbeke \& J. West (Eds.), Open innovation. Researching a new paradigm (pp. 1-12). Oxford: Oxford University Press.

Chesbrough, H. \& Crowther, A.K. (2006). Beyond high tech: early adopters of open innovation in other industries. R\&D Management, 36(3), 229-236.

Child, J., Faulkner, D. \& Tallman, S.B. (2005). Cooperative strategy: managing alliances, networks and joint ventures. Oxford: Oxford University Press.

Chiva, R. \& Alegre, J. (2005). Organizational learning and organizational knowledge: towards the integration of two approaches. Management Learning, 36(1), 49-68.

Cohen, W.M. \& Levinthal, D.A. (1989). Innovation and learning: the two faces of R\&D. The Economic Journal, 99(397), 569-596.

Cohen, W.M. \& Levinthal, D.A. (1990). Absorptive capacity: a new perspective on learning and innovation. Administrative Science Quarterly, 35(1), 128152.

Crossan, M.M., Lane, H.W. \& White, R.E. (1999). An organizational learning framework: from intuition to institution. Academy of Management Review, 24(3), 522-537.

Duchek, S. (2013). Catching absorptive capacity: a critical review and future prospects. Schmalenbach Business Review, July, 312-329.

Ebersberger, B., Herstad, S., Iversen, E., Som, O. \& Kirner, E. (2011). Open innovation in Europe. PRO INNO Europe: INNO-Grips II report. Brussels: European Commission, DG Enterprise and Industry.

Eisenhardt, K. \& Martin, J. (2000). Dynamic capabilities: what are they? Strategic Management Journal, 21(10/11), 1105-1121.

Fey, C. \& Birkinshaw, J. (2005). External sources of knowledge, governance mode and R\&D performance. Journal of Management, 31(4), 597-621.

Fosfuri, A. \& Tribó, J.A. (2008). Exploring the antecedents of potential absorptive capacity and its impact on innovation performance. Omega, 36(2), 173-187.

Gartner, W.B. (1997). When growth is a problem, not the solution. Journal of Management Inquiry, 6(1), 62-68.

Glass, A.J. \& Sagi, K. (1998). International technology transfer and the technology gap. Journal of Development Economics, 55, 369-398.

Huber, G.P. (1991). Organizational learning: the contributing processes and the literatures. Organization Science, 2(1), 88-115. 
Hughes, B, Warenham, J. (2010). Knowledge arbitrage in global pharma: a synthetic view of absorptive capacity and open innovation. $R \& D$ Management, 40(3), 324-343.

Huizingh, E.K.R.E. (2011). Open innovation: state of the art and future perspectives. Technovation, 31, 2-9.

Hunter, S.T., Bedell, K.E. \& Mumford, M.D. (2007). Climate for creativity: a quantitative review. Creativity Research Journal, 19(1), 69-90.

Isaken, S.G., Lauer, K.J., Ekval, G. \& Britz, A. (2001). Perceptions of the best and worst climates for creativity: preliminary validation evidence for situational outlook questionnaire. Creativity Research Journal, 13(2),171184.

Isaken, S.G. \& Ekval, G. (2010). Managing for innovation: the two faces of tension in creative climates. Creativity and Innovation Management, 19(2), 73-88.

Jansen, J.J.P., Van Den Bosch, F.A.J., Volberda, H.W. (2005). Managing potential and realized absorptive capacity: how do organizational antecedents matter? Academy of Management Journal, 48(6), 999-1015.

Jashapara, A. (2004). Knowledge management: an integrated approach, London: Prentice Hall.

Kedia, B.L. \& Bhagat, R.S. (1988). Cultural constraints on transfer of technology across nations: implications for research in international and comparative management. Academy of Management Review, 13(4), 559-571.

Keil, T., Maula, M., Schildt, H. \& Zahra, S.A. (2008). The effect of governance modes and relatedness of external business development activities on innovative performance. Strategic Management Journal, 29(8), 895-907.

Kim, L. (1998). Crisis construction and organizational learning: capability building in catching-up at Hyundai Motor. Organization Science, 9(4), 506-521.

King, A.A. \& Lakhani, K.R. (2011). The contingent effect of absorptive capacity: an open innovation analysis, Working Paper 11-102, Harvard Business School. Retrieved from http://mackinstitute.wharton.upenn. edu/wp-content/uploads/2012/12/KingLakhani_The-Contingent-Effectof-Absorptive-Capacity-An-Open-Innovation-Analysis.pdf

Lane, P.J., Koka B.R. \& Pathak, S. (2006). Reification of absorptive capacity: a critical review and rejuvenation of the construct. Academy of Management Review, 31(4), 833-863.

Lane, P.J. \& Lubatkin, M. (1998). Relative absorptive capacity and interorganizational learning. Strategic Management Journal, 19(5), 461477.

Lane, P.J., Salk, J.E. \& Lyles, M.A. (2001). Absorptive capacity, learning, and performance in international joint ventures. Strategic Management Journal, 22(12), 1139-1161.

Laursen, K. \& Salter, A. (2006). Open for innovation: the role of openness in explaining innovation performance among UK manufacturing firms. Strategic Management Journal, 27(2), 131-150. 
Lee, H., Smith, K.G., Grimm, C. M. \& Schomburg, A. (2000). Timing, order and durability of new product advantages with imitation. Strategic Management Journal, 21(1), 23-30.

Leiponen, A. \& Helfat, C.E. (2010). Innovation objectives, knowledge sources and the benefits of breadth. Strategic Management Journal, 31(2), 224236.

Lewandowska, M.S. (2015). Capturing absorptive capacity: concepts, determinants, measurement modes and role in open innovation. International Journal of Management and Economics, 45, 32-56.

Liao, J., Welsch, H. \& Stoica, M. (2003). Organizational absorptive capacity and responsiveness: an empirical investigation of growth-oriented SMEs. Entrepreneurship Theory and Practice, 28(1), 63-85.

Lis, A. (2013). In search of positive organizational potential: the case of Frauenthal Torun Automotive company. Journal of Positive Management, $4(1), 22-37$.

Lichtenthaler, U. \& Lichtenthaler, E. (2009). A capability-based framework for open innovation: complementing absorptive capacity. Journal of Management Studies, 46(8), 1315-1338.

Loewe, P. \& Dominiquini, J. (2006). Overcoming the barriers to effective innovation. Strategy and Leadership, 34(1), 24-31.

Markman, G.D. \& Gartner, W.B. (2002). Is extraordinary growth profitable? A study of INC. 500 high-growth companies. Entrepreneurship Theory \& Practice, 27(1), 65-75.

Mowery, D.C., Oxley, J.E. \& Silverman, B.S. (1996). Strategic alliances and interfirm knowledge transfer. Strategic Management Journal, 17(S2), 77-91.

Myers, M.D. (2010). Case Study Research. In M. Frenz, K. Nielsen \& G. Walters (Eds.), Research methods in management (pp. 227-248). London: SAGE.

Nahapiet, J. \& Ghosal, S. (1998). Social capital, intellectual capital, and the organizational advantage. Academy of Management Review, 23(2), 242266.

Naldi, L. (2010). Does fortune favor the prepared or the brave firm? Exploring how absorptive capacity affects the growth of international small firms. Academy of Management Perspectives, August, 1-6.

Oshri, I., Pan, S.L. \& Newell, S. (2006). Managing trade-offs and tensions between knowledge management initiatives and expertise development practices. Management Learning, 37(1), 63-82.

Patton, E. \& Appelbaum, S.H. (2003). The case for case studies in management research. Management Research News, 26(5), 60-71.

Rigby, D. \& Zook, C. (2002). Open-market innovation. Harvard Business Review, October, 80-89.

Robertson, P.L., Casali, G.L. \& Jacobson, D. (2012). Managing open incremental process innovation: absorptive capacity and distributed learning. Research Policy, 41, 822-832. 
Rowley, J. (2002). Using case study in research. Management Research News, 25(1), 16-27.

Sapienza, H.J., Autio, E., George, G. \& Zahra, S.A. (2006). A capabilities perspective on the effects of early internationalization on firm survival and growth. Academy of Management Review, 31(4), 914-933.

Schilling, M. (1998). Technological lockout: an integrative model of the economic and strategic factors driving technology success and failure. Academy of Management Review, 23(2), 267-284.

Stake, R.E. (2010). Jakościowe studium przypadku. In: N.K. Denzin, Y.S. Lincoln (Eds.), Metody badań jakościowych (Vol. 1, pp. 623-654). Warszawa: PWN.

Strumińska-Kutra, M. \& Koładkiewicz, I. (2012). Studium przypadku. In: D. Jemielniak (Ed.), Badania jakościowe: Metody i narzędzia (Vol. 2, pp. 1-40). Warszawa: PWN.

Sudolska, A. \& Lis, A. (2014). Building a model of successful collaborative learning for company innovativeness. Journal of Entrepreneurship, Management and Innovation, 10(3), 109-137.

Sun, P.Y.T. \& Anderson, M.H. (2010). An examination of the relationship between absorptive capacity and organizational learning, and a proposed integration. International Journal of Management Reviews, 12(2), 130150.

Teece, D.J. (1998). Capturing value from knowledge assets: the new economy, markets for know-how, and intangible assets. California Management Review, 40(3), 55-79.

Todorova, G. \& Durisin, B. (2007). Absorptive capacity: valuing a reconceptualization. Academy of Management Review, 32(3), 774-786.

Tsai, W. (2001). Knowledge transfer in intraorganizational networks: effects of network position and absorptive capacity on business unit innovation and performance. Academy of Management Journal, 44(5), 996-1004.

Van de Vrande, V., de Jong, J.P.J., Vanhaverbeke, W. \& de Rochemont, M. (2009). Open innovation in SMEs: trends, motives and management challenges. Technovation, 29, 423-437.

Wallin, M.V. \& von Krogh, G. (2010). Organizing for open innovation: focus on the integration of knowledge. Organizational Dynamics, 39(2), 145-154.

Yin, R.K. (2010). Designing case studies. In M. Frenz, K. Nielsen \& G. Walters (Eds.), Research Methods in Management (pp. 185-226). London: SAGE.

Zahra, S.A. \& George, G. (2002). Absorptive capacity: a review, reconceptualization, and extension. Academy of Management Review, 27(2), 185-203.

Zahra, S.A., Ireland, R. \& Hitt, M.A. (2000). International expansion by new venture firms: international diversity, mode of market entry, technological learning and performance. Academy of Management Journal, 43(5), 925-950. 


\section{Abstrakt (in Polish)}

Celem artykułu jest dokonanie analizy roli i znaczenia zdolności organizacji do absorpcji wiedzy zewnętrznej dla wzrostu przedsiębiorstwa i budowania jego przewagi konkurencyjnej poprzez innowacje. Przypadek przedsiębiorstwa Frauenthal Automotive Toruń został wykorzystany do zbadania w jaki sposób działania i dobre praktyki zwiqzane ze zdolnościq organizacji do absorpcji wiedzy zewnętrznej wpływajq na jej wzrost i sukces biznesowy. W wyniku operacjonalizacji celu głównego określono trzy cele szczegółowe: (1) zidentyfikowanie we Frauenthal Automotive Toruń doświadczeń i dobrych praktyk w zakresie procesów absorpcji wiedzy zewnętrznej; (2) dokonanie analizy relacji pomiędzy koncepcjami zdolności organizacji do absorpcji wiedzy zewnętrznej i otwartych innowacji; (3) wskazanie i dokonanie analizy przykładów wykorzystania przez Frauenthal Automotive Toruń zdolności do absorpcji wiedzy zewnętrznej w celu tworzenia innowacji, rozwoju i wzrostu przedsiębiorstwa oraz jego przewagi konkurencyjnej.

Słowa kluczowe: zdolność organizacji do absorpcji wiedzy zewnętrznej, otwarte innowacje, wzrost przedsiębiorstwa, przewaga konkurencyjna.

\section{Biographical notes}

Andrzej Lis, Ph.D., is an Assistant Professor at the Faculty of Economic Sciences and Management, Nicolaus Copernicus University, Toruń and a staff officer of the Doctrine and Training Centre of the Polish Armed Forces, Bydgoszcz. His area of research activity encompasses the issues of knowledge management, change management, defense industry and military logistics, whereas the main research interest is focused on Lessons Learned processes.

Agata Sudolska, Ph.D., is an Associated Professor at the Faculty of Economic Sciences and Management, Nicolaus Copernicus University, Toruń. Her area of interests and research activities encompasses the issues of the process of creating innovations as well as managing inter-firm relationships and networks, in particular with the focus on knowledge exchange and collaborative learning. 
